\title{
THE ECONOMIC GROWTH FORECAST AND A REVIEW OF THE IMPACTS OF COVID-19 ON THE GHANAIAN ECONOMY: APPLICATION OF TIME SERIES ANALYSIS AND MONTE-CARLO SIMULATION
}

\author{
Professor Li Fang Lin ${ }^{1}$ \\ Professor, School of Finance and Economics, Jiangsu University No.301 Xuefu Road, Zhenjiang,
} 212013, Jiangsu Province, P. R. China .

\section{Blessed Kwasi Adjei ${ }^{2 *}$}

Masters Student, School of Finance and Economics, Jiangsu University No.301 Xuefu Road, Zhenjiang, 212013, Jiangsu Province, P. R. China ${ }^{2}$.

\section{Felix Kwame Nyarko ${ }^{3}$}

PHD Candidate, School of Finance and Economics, Jiangsu University No.301 Xuefu Road, Zhenjiang, 212013, Jiangsu Province, P. R. China ${ }^{3}$.

\begin{abstract}
This manuscript explores the effects of Covid-19 pandemic on the economic activities of Ghana by first modelling the Economic growth figures of Ghana; discuss the current covid-19 situation and its economic impact on the nation and to wrap things up by suggesting remedial measures necessary to salvage the situation at hand. To model and forecast the Economic growth trend, the times series analysis and the Monte Carlo simulation (Laplace distribution) techniques were employed. The success of the ARIMA model was monitored through Akaike information Criterion (AIC) where irrefutably the absolute number shows the success of the model - the lower the number, the better the model.

The research results showed that in spite of promising economic forecasts, with the force of the pandemic soaring universally, there is no doubt that the economic prosperity of Ghana will be disrupted and major revenue margins shrinked this year. However, due to some solid and harsh measures set out by the government we are optimistic that situations will be well contained and managed. The scientific contribution of the research lies in the fact that it will offer a new way of perceiving risks and uncertainties when policy makers are drafting budgets and economic policies going forward. In that capacity, they will not only adapt to practical and analytical methods to forecast but additionally consider some unforeseen circumstances beyond the control of humanity that may have tormenting impact on economic outputs.
\end{abstract}

KEYWORDS: Time series analysis, Covid-19, Monte-Carlo simulation, GDP per Capita, Modelling, Economic Growth. 


\section{SJIF Impact Factor: 7.001| ISI I.F.Value:1.241| Journal DOI: 10.36713/epra2016 \\ ISSN: 2455-7838(Online) \\ EPRA International Journal of Research and Development (IJRD) \\ Volume: 5 | Issue: 7 | July 2020 \\ - Peer Reviewed Journal}

\section{INTRODUCTION}

A fundamental method to gauge a nation's Economic development and prosperity is by following its GDP per capita performances year on year. These figures by and large show how much the economic production value can be credited to every individual resident. Governments then again broadly use GDP per capita to understand how the economy is developing with its populace hence it is important for us to focus on this variable's contribution to understand how an economy is growing or contracting in terms of its people.

Theoretically, if a country's GDP per capita is growing with a stable population level it can conceivably be the consequence of innovative strategies that are producing more with the same population size. Some countries may have high GDP per capita but a small population and this may mean that they have built up a self-sufficient economy based on an abundance of special resources. Notwithstanding, a country may have predictable economic growth but if its population is growing faster than its GDP, then GDP per capita will be on a descending pattern. This is normally the situation of numerous African countries. There are many speculations concerning why African countries are so poor. One of the most credible reasons is essentially a direct result of the populace and economic size. Small economies in Africa mostly find it difficult building economies of scale as compared to other advance nations. Also, numerous African nations are landlocked, which means they don't have direct access to the global exchanging partners. They depend on neighbouring nations to get their products to the global market. This move increases their operative cost and results in less competitive prices. Indeed, even African nations with ports face enormous transportation costs in getting their products to other foreign markets.

More importantly, global forecast of per capita GDP helps provide comparable insight on economic prosperity and economic developments across the globe. Both GDP and population are factors in the per capita equation. The IMF therefore provides a regular outlook on global growth with insights on both GDP and GDP per capita. As per the estimates it expects little change in the rankings of the best ten (10) nations as drowsy growth data is trending across the globe. The IMF expects GDP growth worldwide of $3.2 \%$ in 2019 to marginally pickup in 2020 to $3.5 \%$. The IMF's 2019 and 2020 per capita GDP expected rankings include the following:

\begin{tabular}{|c|c|c|}
\hline \hline Country & $\begin{array}{c}\text { GDP Per Capita } \\
\text { (USD, 2019) }\end{array}$ & $\begin{array}{c}\text { GDP Per Capita } \\
\text { (USD, 2020) }\end{array}$ \\
\hline Luxembourg & $\$ 113,200$ & $\$ 116,730$ \\
\hline Switzerland & $\$ 83,720$ & $\$ 86,670$ \\
\hline Macao SAR & $\$ 81,150$ & $\$ 80,070$ \\
\hline Norway & $\$ 77,980$ & $\$ 78,330$ \\
\hline Ireland & $\$ 77,770$ & $\$ 80,260$ \\
\hline Qatar & $\$ 69,690$ & $\$ 70,740$ \\
\hline Iceland & $\$ 67,040$ & $\$ 66,600$ \\
\hline United States & $\$ 65,110$ & $\$ 67,430$ \\
\hline Singapore & $\$ 63,990$ & $\$ 64,830$ \\
\hline Denmark & $\$ 59,800$ & $\$ 61,730$ \\
\hline \hline
\end{tabular}

TABLE 1. GDP per Capita forecast by IMF for top 10 GDP per capita countries

These forecasts are profoundly significant as they can assume a significant job in advancing the economic success or failure of a country. Likewise it diminishes vulnerability such as economic downturn, recession and other risks beyond human control and sufficiently helps policy makers to envision change in the economic conditions. Some other benefits are the abundance of information made accessible to people of these nations. Moreover, a promising forecast is compelling to investors who may be keen on putting money into a country.

\subsection{Significance of the Research}

This research mainly seeks to employ time series models and the Monte Carlo simulation techniques to first predict the economic growth trend of Ghana, discuss the current economic situation of Ghana and how the Covid-19 pandemic will take its toll on the economy and lastly put across some mitigating strategies planned out by the Government to tone down the effects of the pandemic and also add some few policy suggestions. The outcome of the study will have a long term effect on the economy even after the pandemic is long gone since policy makers will be more guided henceforth to put into consideration certain uncontrolled risks factors when making economic policies and drafting budgets for the years ahead. 


\title{
EPRA International Journal of Research and Development (IJRD)
}

\author{
Volume: 5 | Issue: 7 | July 2020 \\ - Peer Reviewed Journal
}

To perform this analysis, we obtained the yearly GDP per capita and population datasets from the World Bank indicators site and it spanned from 1960 to 2019. Also we collected the datasets on Ghana's covid-19 cases from Statista. The first being the GDP per capita will be the data to model and predict the economic trends of Ghana. Then again the population data and that on the covid-19 cases will be used to legitimize the need to concentrate on unexpected conditions that tend to affect economic trends in Ghana going forward.

GDP per Capita
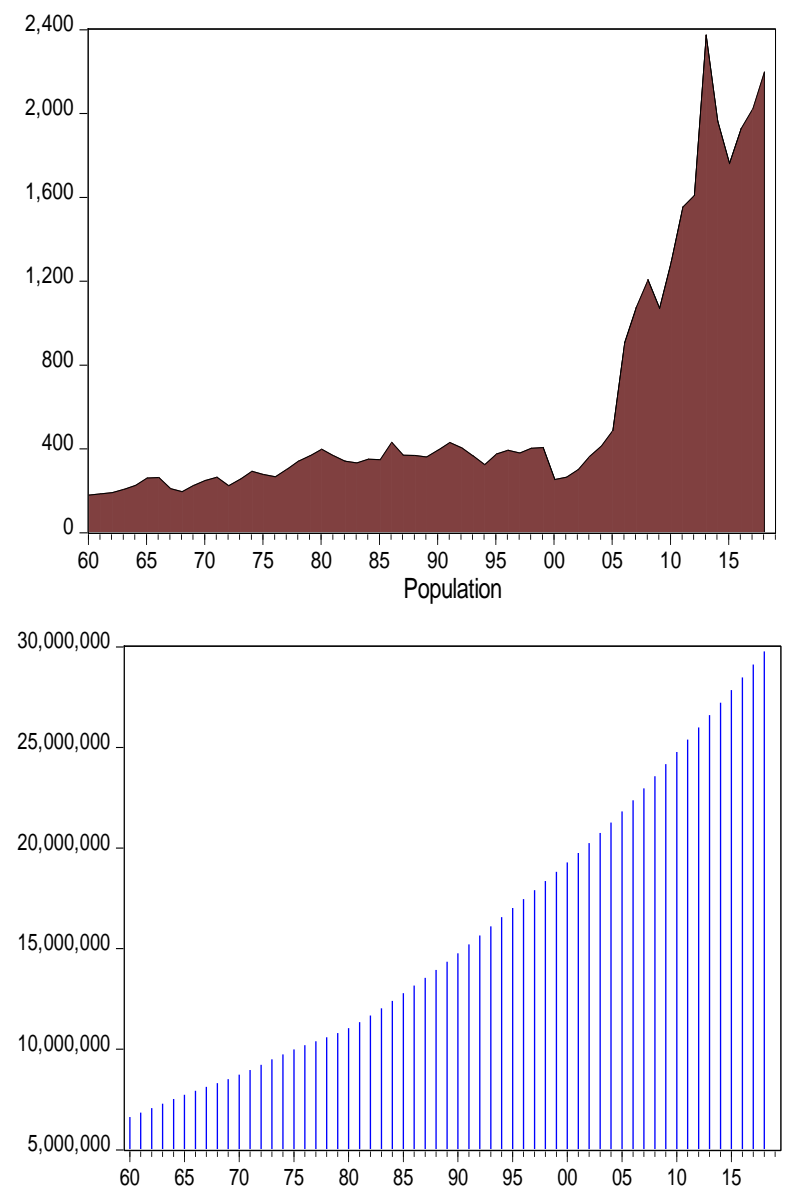

Figure 1 Raw data of GDP per Capita and Population of Ghana

\section{PROBLEM STATEMENT}

As the adage goes "anyone who has seen a convertible trapped in a rainstorm comprehends the significance of weather forecasts", a similar relationship can be ascribed to economic forecasts. Economies as compared to the weather can be particularly questionable now and again and thus the requirement for computations and predications. These figures build confidence and assurance in an economy and causes people to feel progressively hopeful about what's to come. Nonetheless, in spite of how precise or careful these forecasts might be there are always some sorts of environmental uncertainties that are beyond the control of mankind and for which individuals ordinarily think little of. Instead of believing the entirety of any predictions about the future, we ought to consistently as a country attempt to create plans that will be delicate to shocks.

Taking a gander at the great economic recession of 2008 that devastated world financial markets just as the banking and real estate industries made a huge number of individuals lose their life savings, their jobs and their homes, the Great depression that endured from 1929 to 1939 and made a huge number of financial specialists loose immense total of cash because of the crash in the stock market, it is very much certain that this pandemic would have a drastic impact on economies after the circumstance is at long last managed. To the developing economies like Ghana some of the problems attributable to the covid-19 


\section{SJIF Impact Factor: 7.001| ISI I.F.Value:1.241| Journal DOI: 10.36713/epra2016 \\ ISSN: 2455-7838(Online) \\ EPRA International Journal of Research and Development (IJRD) \\ Volume: 5 | Issue: 7 | July 2020 \\ - Peer Reviewed Journal}

will be the difficulties going to be encountered in handling the effects of the crisis, since the amount of aid needed to fight the virus will be much greater than the resources available to cushion the threats of the lockdown. In addition, the health care available to most people in Africa is much poorer. Another problem that will be witnessed massively is the increment in capital flights from developing economies by multinationals.

\section{TIME SERIES MODELLING AND FORECASTING}

Time series datasets are series of time dependent recordings of processes or phenomena. Typically these recordings can either be continuous in nature or discrete observations. A time series containing records of a single variable is termed as univariate. In any case, if records of more than one variable are thought of, it is named as multivariate. In this paper we will concentrate on the scenario where observations are made at discrete equally spaced times. The consecutive observations of the discrete datasets are recorded at equal time intervals and mathematically defined as a set of vectors $x(t), t=0,1,2 \ldots$ Where $t$ represents the time elapsed.

Generally speaking one vital concept worth noting with time series analysis is stationarity. Simplistically, stationary time series process exhibit invariant properties over time with respect to the mean and variance of the series. Meaning its behaviour does not change over time or that their values always tend to vary about the same level and that their variability is constant over time. On the other hand for non-stationary time series, the mean, variance or both will change over the trajectory of the time series. The importance of stationary time series to a research is its ability to succinctly give a more valid representation when used to develop analytical models against which forecasts can be produced. Through a process of differencing, non-stationary time series datasets can be reduced to stationary time series. Although there are a number of things which are of interest in time series analysis, our research will focus on two vital purpose; Modelling and Forecasting.

Time series modelling is a powerful research area which involves carefully collecting and rigorously studying the past observations of a time series to develop an appropriate model which describes the inherent structure of the series. This model may depend on unknown parameters and these will need to be estimated. This model is then used to generate future values for the series, i.e. to make forecasts. Time series forecasting thus can be termed as predicting what the value of $\mathrm{Y}_{\mathrm{t}}+\mathrm{M}$, (M $\geq 1$ ) will be and possibly give an indication of what the uncertainty is in the prediction. It is obvious that a successful time series forecasting depends on an appropriate model fitting. One of the most popular and frequently used stochastic time series models is the Autoregressive Integrated Moving Average (ARIMA) model which will also be used in this study. The basic assumption made to implement this model is to consider the time series as linear and also that it follows a particular known statistical distribution, such as the normal distribution. ARIMA model has subclasses of other models, such as the Autoregressive (AR), Moving Average (MA) and Autoregressive Moving Average (ARMA) models. The popularity of the ARIMA model is mainly due to its association with the Box-Jenkins methodology (George Box and Gwilym Jenkins, 1970) for optimal model building process which postulates the following intuitive steps;

$>$ Identifying whether the time series is stationary or not, how many differences are required to make it stationary, plotting the Autoregressive plots and partial autoregressive plots. Both plots are drawn as bar charts showing the $95 \%$ and $99 \%$ confidence intervals as horizontal lines. Bars that cross these confidence intervals are therefore more significant and worth noting.

$>$ Estimating the data to train the parameters of the model (i.e. the coefficients).

$>$ Doing a diagnostic Check of the fitted model in the context of the available data and check for areas where the model may be improved.

\subsection{Establishing the stationary assumption}

The basic prerequisite of time series modelling is that the stationary of our GDP per capita time series data needs to be established. Here two measures are presented to verify the stationary of the data (the subjective and the objective). Each of these processes has its merits and demerits. The subjective method is based on the idea of illustrative assessment of the correlogram of autocorrelations and partial-autocorrelations at different lag levels. The objective method is more mathematically inclined and uses the Unit Root Tests and the Augmented Dickey Fuller (ADF). Within this study both the objective and subjective measures are used for checking the stationarity of the data set. If it is not stationary, that is $\mathrm{I}(0)$, then we will have issues with auto-correlation in our residuals, which violates an essential assumption made by many statistical models and theories. The disadvantage of a model based on non-stationary datasets would be its bad predictive ability, hence implying we apply first or second level 


\section{EPRA International Journal of Research and Development (IJRD)}

differencing. It is therefore appropriate to accept that stationary will imply that the mean and variance of the series do not vary over time.

\subsubsection{Unit root test}

Considering the approach to unit root testing we implicitly assume that the time series to be tested can be written in the form $Y \boldsymbol{t}=\boldsymbol{D} \boldsymbol{t}+$ $\boldsymbol{Z} \boldsymbol{t}+\boldsymbol{\varepsilon} \boldsymbol{t}$. Where,

- $\mathrm{D}_{\mathrm{t}}$ is the deterministic component (trend, seasonal component, etc.)

- $\mathrm{Z}_{\mathrm{t}}$ is the stochastic component.

- $\varepsilon_{\mathrm{t}}$ is the stationary error process

The task of the test is to determine whether the stochastic component contains a unit root or is stationary. Autoregressive unit root tests are based on testing the null hypothesis that $\varphi=1$ (difference stationary) against the alternative hypothesis that $\varphi$ $<1$ (trend stationary). They are called unit root tests because under the null hypothesis the autoregressive polynomial of $\mathrm{zt}, \varphi(\mathrm{z})=(1-\varphi \mathrm{z})=$ 0 , has a root equal to unity.

\subsubsection{The Augmented Dickey Fuller test}

The time series data are subjected to the Augmented Dickey fuller test to verify if the null hypothesis has a unit root present in a time series sample. The augmented version of the Dickey-Fuller test is used instead of just the Dickey fuller test due to the large and more complicated nature of the time series models. The testing procedure for the ADF test is the same as for the Dickey-Fuller test but it is applied to the model where $\mathrm{c}$ is a constant, $\beta$ the coefficient on a time trend and $\theta$ the lag order of the autoregressive process as represented in the mathematical equation below:

$$
\mathbf{Y t}=\underset{\text { Imposing the constraints } c=0 \text { and } \beta=0}{\mathbf{c}+\boldsymbol{\beta} \mathbf{t}+\boldsymbol{\theta} \mathbf{y t}-\mathbf{1}+\boldsymbol{\theta} \mathbf{t}-\mathbf{1}+\boldsymbol{\varepsilon} \mathbf{t}}
$$

corresponds to modelling a random walk and using the constraint $\beta=0$ corresponds to modelling a random walk with a drift. By including lags of the order $\theta$ the ADF formulation allows for higherorder autoregressive processes. This means that the lag length $\theta$ has to be determined when applying the test. One possible approach is to test down from high orders and examine the t-values on coefficients. An alternative approach is to examine information criteria such as the Akaike information criterion, Bayesian information criterion or the Hannan-Quinn information criterion. The unit root test is then carried out under the null hypothesis $\varphi=0$ against the alternative hypothesis of $\varphi<0$. If the $p$-value is less than the confidence level (alpha value), then the null hypothesis of $\varphi=0$ is rejected and no unit root is present else we accept the null hypothesis and apply

\begin{tabular}{|c|c|c|c|}
\hline \multirow{2}{*}{$\begin{array}{l}\text { TABLE } 2 \\
\text { AT LEVEL }\end{array}$} & \multicolumn{3}{|c|}{ Exogenous: Constant } \\
\hline & & t-Statistic & Prob.* \\
\hline Augmented Dickey-Fuller test statistic & & 0.964196 & 0.9957 \\
\hline \multirow[t]{3}{*}{ Test critical values: } & 1\% level & -3.548208 & \\
\hline & $5 \%$ level & -2.912631 & \\
\hline & $10 \%$ level & -2.594027 & \\
\hline AT FIRST DIFFERENCE & & t-Statistic & Prob.* \\
\hline Augmented Dickey-Fuller test statistic & & -7.994268 & $0.0000^{* * *}$ \\
\hline \multirow[t]{3}{*}{ Test critical values: } & 1\% level & -3.550396 & \\
\hline & $5 \%$ level & -2.913549 & \\
\hline & $10 \%$ level & -2.594521 & \\
\hline
\end{tabular}
differencing.

\section{Note: ${ }^{* * *}$ indicates $1 \%$ significance, ${ }^{* *}$ indicates $5 \%$ significance and * indicates $10 \%$ significance}

After the ADF tests (both at level and at first difference) are applied. . The null hypothesis of having unit root is not rejected at level since the $\mathrm{p}$ value of the test statistic exceeds the observed level of significance $=0.05$. From Table 2 the results of ADF test on GDP per Capita at level indicates that the hypothesis: GDP has a unit root, is acknowledged meaning the series is non stationary at level. However at first difference the ADF test evidently indicates that the series is stationary with a $p$-value being less than 0.05 . (i.e $\mathrm{p}$-value $=0.0000$ )

\subsection{The Auto-Correlation Function Plot}

The line of the Auto-Correlation Function (ACF) shows strong positive auto-correlation for the first 12 lags. Then there is a long period of negative auto-correlation for the last 12 lags. This is a good indication that the GDP per capita is non-stationary at level and hence differencing is to be applied to convert it to stationary series. The ACF plot for the differenced GDP per capita, however, becomes stationary. This suggests the GDP per capita is I(1). 
Figure 2. The Auto-correlation function (ACF) at level

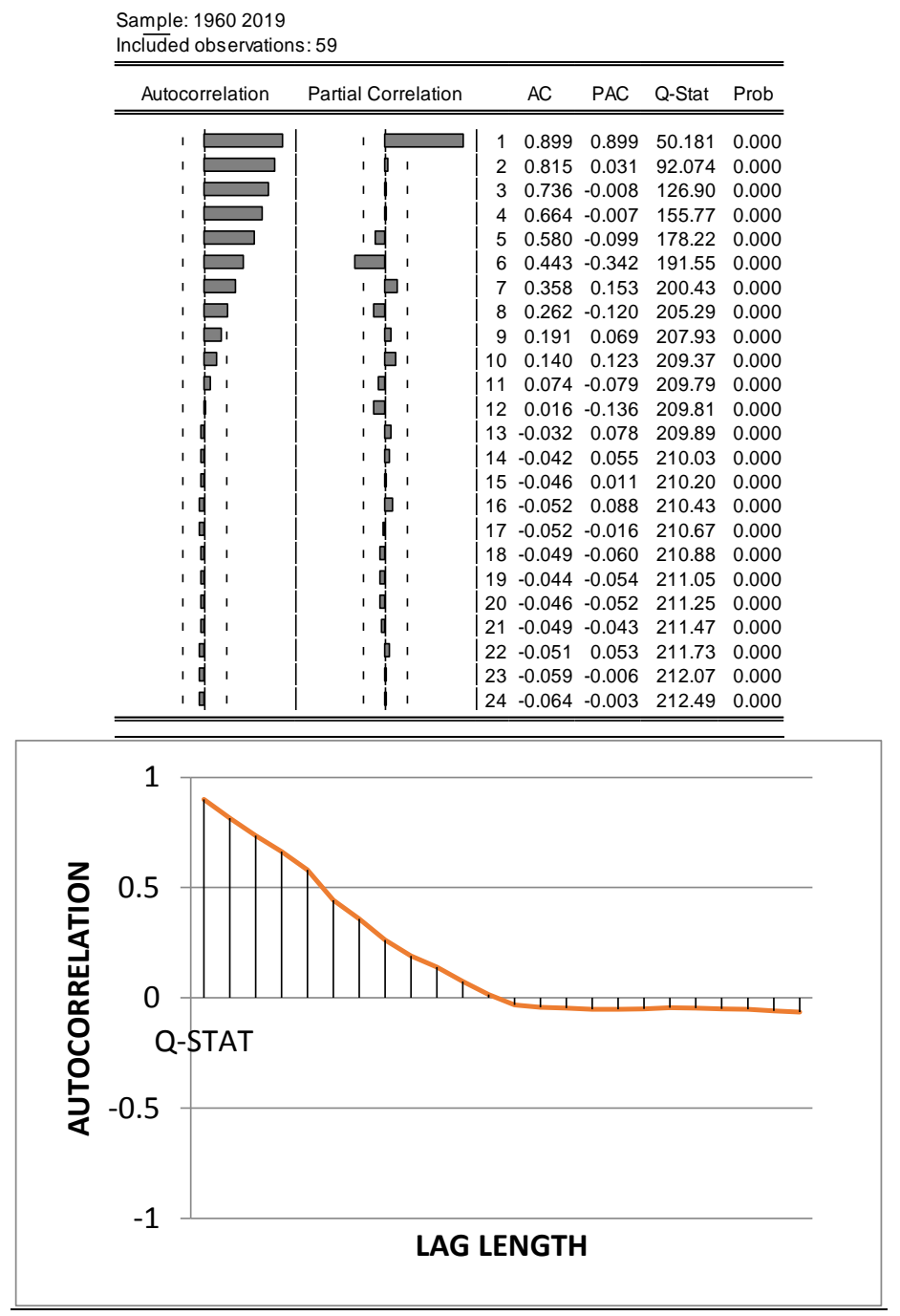

The ACF is presented as graphical plots. The ACF of the non-stationary process shows a gentler decline to zero. Figure 2 replicates the ACF for a non-stationary GDP per Capita. Conversely, Figure 3 below provides a scenario of a stationary time series with the associated ACF diagram. From the observations of the stationary time series it shows little or no correlation and is reflected in the ACF plot showing a rapid decline to zero. This means the GDP per capita is integrated to the order 1 and will need to be differenced one time for modelling. 
Figure 3. The Auto-correlation function (ACF) at first difference

Sample: 19602019 Included observations: 58

\begin{tabular}{|c|c|c|c|c|c|c|}
\hline Autocorrelation & Partial Correlation & & AC & PAC & Q-Stat & Prob \\
\hline 101 & 1 प] 1 & & -0.082 & -0.082 & 0.4072 & 0.523 \\
\hline 101 & 101 & & -0.030 & -0.037 & 0.4623 & 0.794 \\
\hline 101 & 101 & 3 & 0.069 & 0.064 & 0.7663 & 0.858 \\
\hline 101 & 10 & & -0.119 & -0.110 & 1.6754 & 0.795 \\
\hline । $\square$ & ' $\square$ & 5 & 0.287 & 0.280 & 7.1021 & 0.213 \\
\hline 1 & ， 口 & 6 & 0.096 & 0.132 & 7.7191 & 0.259 \\
\hline । 口। & ' $\square$ & & 0.186 & 0.268 & 10.077 & 0.184 \\
\hline 1 प 1 & 미 1 & & -0.108 & -0.126 & 10.883 & 0.208 \\
\hline 101 & 171 & 9 & -0.056 & -0.003 & 11.103 & 0.269 \\
\hline 11 & 101 & 10 & 0.039 & -0.099 & 11.214 & 0.341 \\
\hline 111 & 11 & 11 & 0.007 & -0.000 & 11.217 & 0.425 \\
\hline 11 & 口 & 12 & 0.024 & -0.178 & 11.261 & 0.507 \\
\hline 1 1 1 & 1 민 & 13 & -0.103 & -0.119 & 12.088 & 0.520 \\
\hline 11 & 1 1 1 & 14 & 0.016 & -0.033 & 12.110 & 0.597 \\
\hline 101 & ' 口1 & 15 & 0.061 & 0.174 & 12.407 & 0.648 \\
\hline 10 & 111 & 16 & -0.028 & 0.013 & 12.473 & 0.711 \\
\hline 11 & 11 & 17 & -0.015 & 0.037 & 12.491 & 0.770 \\
\hline 11 & 101 & 18 & -0.020 & 0.038 & 12.526 & 0.819 \\
\hline 1 d 1 & 111 & 19 & -0.087 & -0.007 & 13.198 & 0.828 \\
\hline 111 & 1 d 1 & 20 & -0.004 & -0.066 & 13.199 & 0.869 \\
\hline 111 & 1 d । & 21 & 0.003 & -0.102 & 13.200 & 0.901 \\
\hline 101 & 11 & 22 & 0.031 & -0.024 & 13.293 & 0.925 \\
\hline 11 & 101 & 23 & -0.044 & -0.045 & 13.487 & 0.941 \\
\hline 101 & 111 & 24 & -0.062 & -0.016 & 13.875 & 0.949 \\
\hline
\end{tabular}

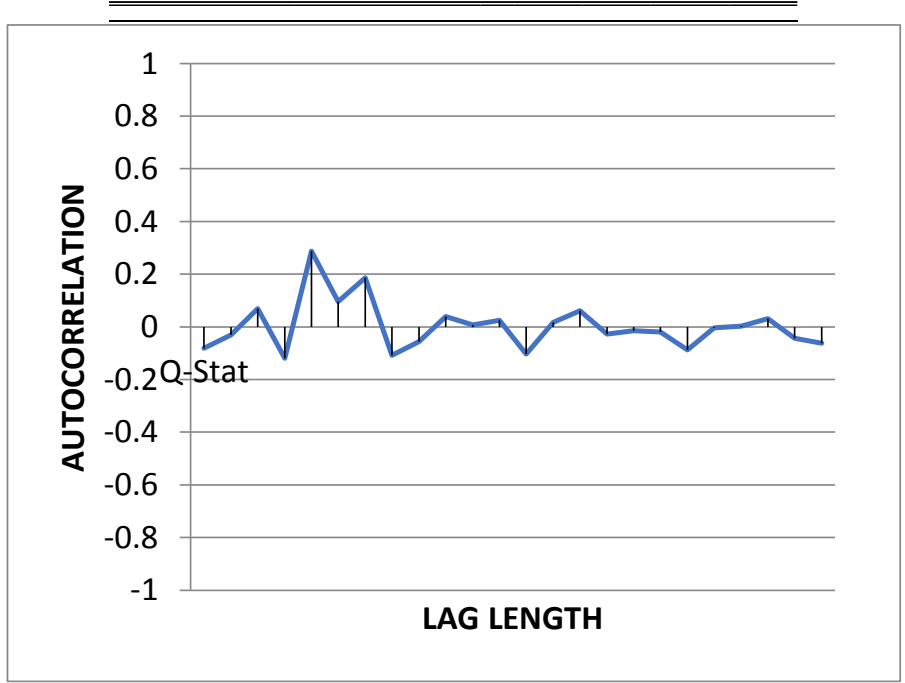

3.3 Estimating possible ARIMA Models and selection

From the initial intuition of Box-Jenkins methodology, which is more prevalent on recognition, to come across the appropriate values of $\mathrm{p}$ (Auto-regressive term), d (no of difference taken) and $\mathrm{q}$ (moving average term) for time series modelling, it is of best interest we focus on the presentations of correlogram of the auto-correlations and partial auto-correlations. The significance of $p$ is obtained from correlogram of partial autocorrelations and the significance of $q$ is attained from the correlogram of auto-correlation.From the correlogram of auto-correlations and partial autocorrelations of the first differenced GDP per Capita in Figure 3 above, it can be seen that significance is achieved at the 5th and 7th points. Therefore two tentative ARIMA Models can be deduced and the best model that fit the series be estimated. Other diagnostic test would be carried out to determine if all the variables have been covered by the applicable model. The two tentative models are ARIMA $(5,1$, $5)$ and $\operatorname{ARIMA}(5,1,7)$. 


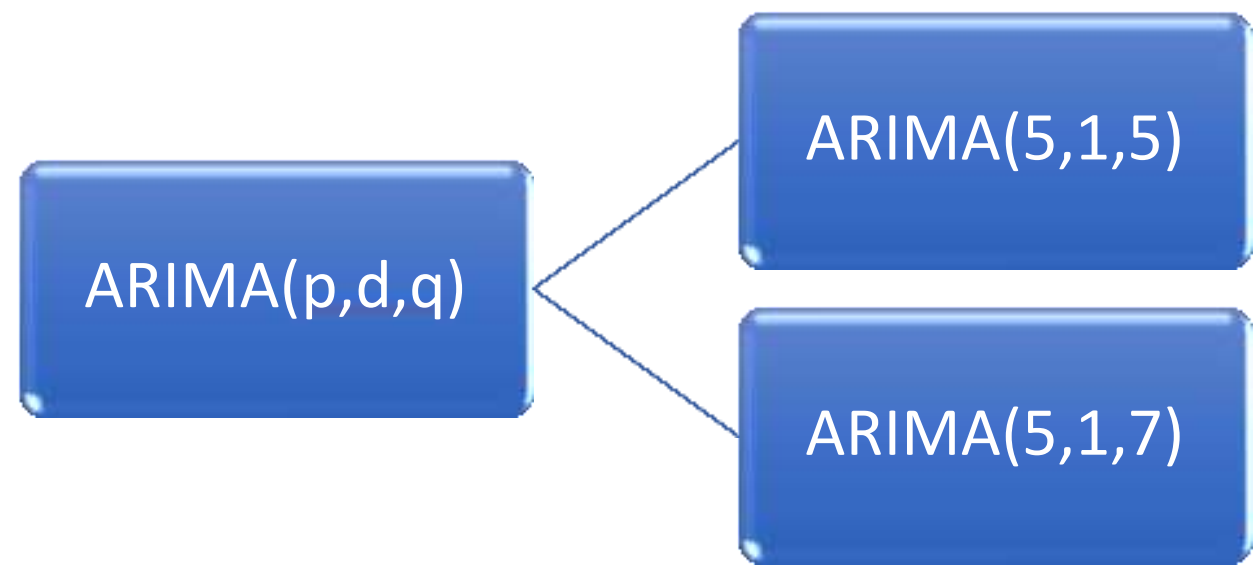

Figure 4 possible ARIMA Model

TABLE 3 ARIMA Model Outputs

\begin{tabular}{|c|c|c|c|c|c|c|c|}
\hline \multirow{3}{*}{\multicolumn{4}{|c|}{$\begin{array}{c}\text { ARIMA }(5,1,5) \\
\text { Dependent Variable: D(GDP per Capita) } \\
\text { Method: ARMA Maximum Likelihood (OPG - BHHH) }\end{array}$}} & \multicolumn{4}{|c|}{ ARIMA $(5,1,7)$} \\
\hline & & & & \multirow{2}{*}{\multicolumn{4}{|c|}{$\begin{array}{c}\text { Dependent Variable: D(GDP per Capita) } \\
\text { Method: ARMA Maximum Likelihood (OPG - BHHH) }\end{array}$}} \\
\hline & & & & & & & \\
\hline Variable & Coefficient & $\mathrm{t}$-Statistic & Prob. & Variable & Coefficient & $\mathrm{t}$-Statistic & Prob. \\
\hline $\mathrm{C}$ & 30.9529 & 0.9106 & 0.3665 & $\mathrm{C}$ & 28.3759 & 0.5636 & 0.5753 \\
\hline $\mathrm{AR}(5)$ & -0.18504 & -0.3368 & 0.7375 & $A R(5)$ & 0.33430 & 2.4510 & $0.0175^{\star *}$ \\
\hline $\operatorname{MA}(5)$ & 0.57247 & 1.0063 & 0.3188 & $\mathrm{MA}(7)$ & 0.35708 & 3.4341 & $0.0011^{* * \star}$ \\
\hline SIGMASQ & 18527.83 & 8.7208 & $0.0000^{* * *}$ & SIGMASQ & 17445.99 & 9.5253 & $0.0000^{* \star \star}$ \\
\hline F-statistic & 2.5305 & AIC & 12.8207 & F-statistic & 3.803719 & AIC & 12.7693 \\
\hline $\begin{array}{l}\text { Prob(F- } \\
\text { statistic) }\end{array}$ & $0.0667^{*}$ & $\begin{array}{l}\text { Durbin-Watson } \\
\text { stat }\end{array}$ & 2.1983 & $\begin{array}{l}\text { Prob(F- } \\
\text { statistic) }\end{array}$ & $0.015133^{* *}$ & $\begin{array}{l}\text { Durbin- } \\
\text { Watson stat }\end{array}$ & 2.1204 \\
\hline
\end{tabular}

Note: *** indicates 1\% significance, ${ }^{* *}$ indicates 5\% significance and * indicates $10 \%$ significance

From Table 3 it can be observed that between the two models, ARIMA $(5,1,7)$ is the best model to be employed for forecasting. The criteria used in selection were based the highest number of significant values (3 significant coefficients), the least volatility (SIGMASQ), the lowest Akaike info criterion (AIC) and lastly the significance of the Fstatistics.

\subsection{Time series analysis forecast of the GDP per capita}

The graph below as observed in Figure 5 indicates the plot of the forecasted GDP per Capita and actual GDP per capita figures. Despite some little variations between the forecasted GDP per capita and the actual from 2011 to 2015 it can be seen that both lines have been on an upward trend over the years. An extrapolation therefore of both lines will indicate the GDP figures of Ghana will continue on its upward trend. 


\section{EPRA International Journal of Research and Development (IJRD)}
Volume: 5 | Issue: 7 | July 2020
- Peer Reviewed Journal

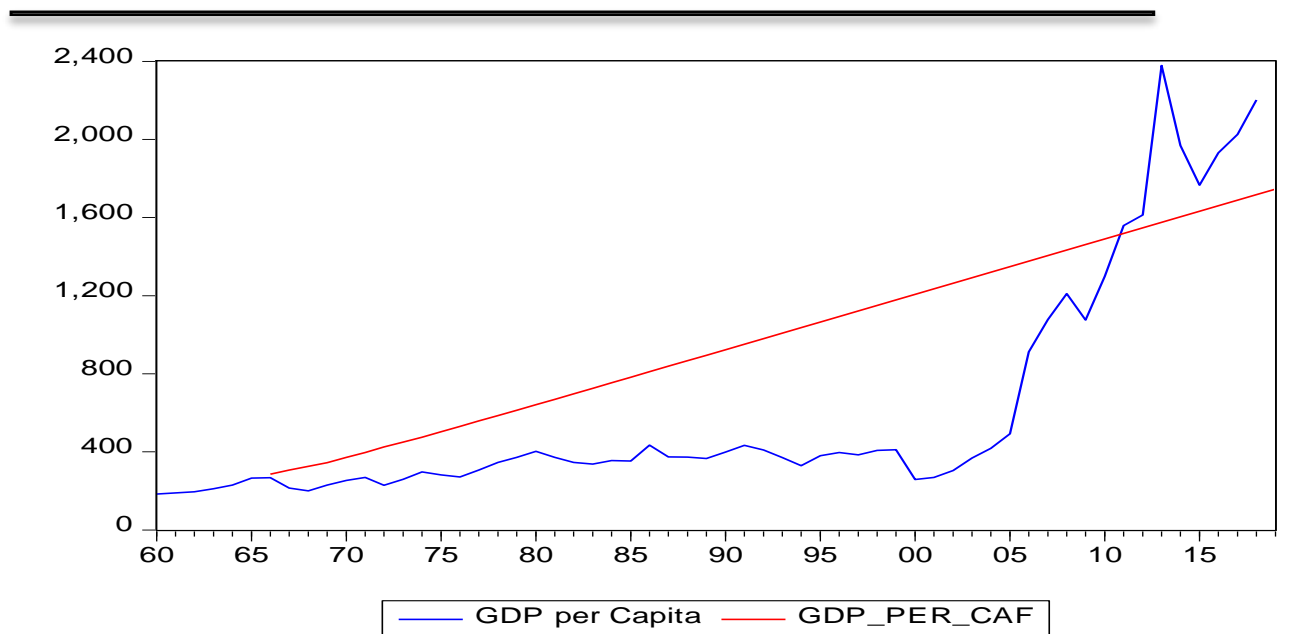

Figure 5. Graph of the forecasted GDP per capita vs. Actual GDP per capita figures

\section{PREDICTING GDP PER CAPITA BY MONTE CARLO SIMULATION}

Every now and again, in real world situations because of the unpredictability of economic uncertainties it may not be conceivable to assess precisely the economic behaviour by applying analytical methods. Under such conditions an alternative approach to model such system is through creating a simulation. Concisely, simulation methods provide an alternative approach to studying economic and financial behaviour through creating an artificial replication of real economic data series.

The strategy mimics sets of random figures from the underlying probability distribution of the process under investigation. A particular utilization of the Monte Carlo method is dependent on the nature of the underlying probability distribution of the process under investigation.

\subsection{Picking a Distribution for the Prediction (Laplace Distribution)}

After choosing the simple ARIMA model of order $(5,1,7)$, its residuals are carefully examined. From Figure 6 the plots of the residuals appear stationary with the mean of the distributions being roughly zero, hence indicating that the residuals are distributed normally. If a line is drawn through the histogram, it will be roughly bell-shaped and centered at 0 . The fitting function indicates the Laplace distribution is a reasonable distribution to use for our Monte Carlo simulations, because it has tails heavier than the Normal distribution and more suitable for the modelling of financial returns and economic trends. 
Figure 6. Residual plot the selected ARIMA model
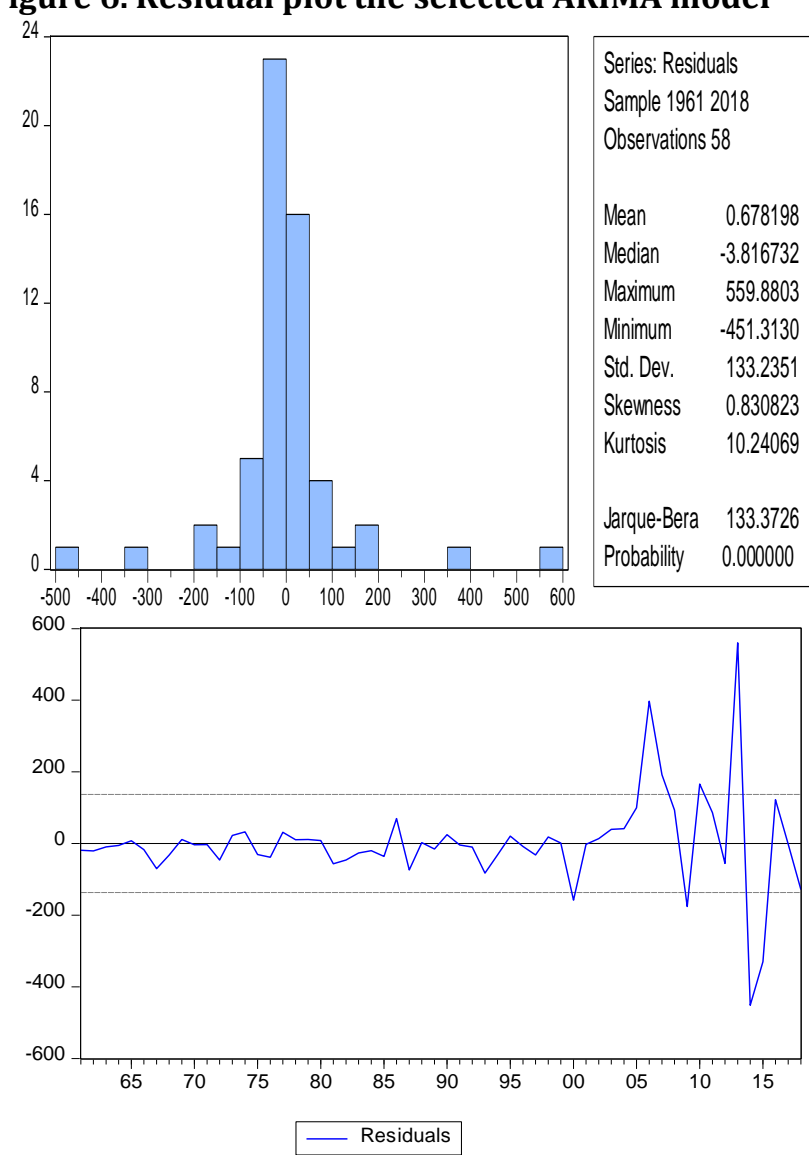

\subsection{Monte Carlo Simulation (Predicting} using Laplace distribution)

Now we can generate empirically derived prediction intervals using our chosen distribution (Laplace).By definition the Laplace distribution will be modelled mathematically as:

$$
\mathrm{p}(\mathrm{x})=\frac{1}{2 \mathrm{~b}} \mathrm{e}^{-|\mathrm{x}-\mathrm{u}| / \mathrm{b}} \text { and } b=\frac{1}{N} \sum_{1}^{N}|x-u|
$$

The mean is the predicted GDP per capita, because the residuals were centered at zero. The beta is calculated from the residuals as the mean absolute distance from the mean. It is a way of measuring the length of the tails. The percentage of actual GDP per capita values within our prediction interval is $100 \%$ (other runs had it around $99.6 \%$ prediction intervals hence does not seem too wide). We plotted the prediction intervals along with the actual GDP per capita values and the actual GDP per capita values do appear exactly as we want. 


\section{EPRA International Journal of Research and Development (IJRD)}

Figure 7.Forecasted GDP per capita vs. Actual GDP per capita figures (Simulation technique)

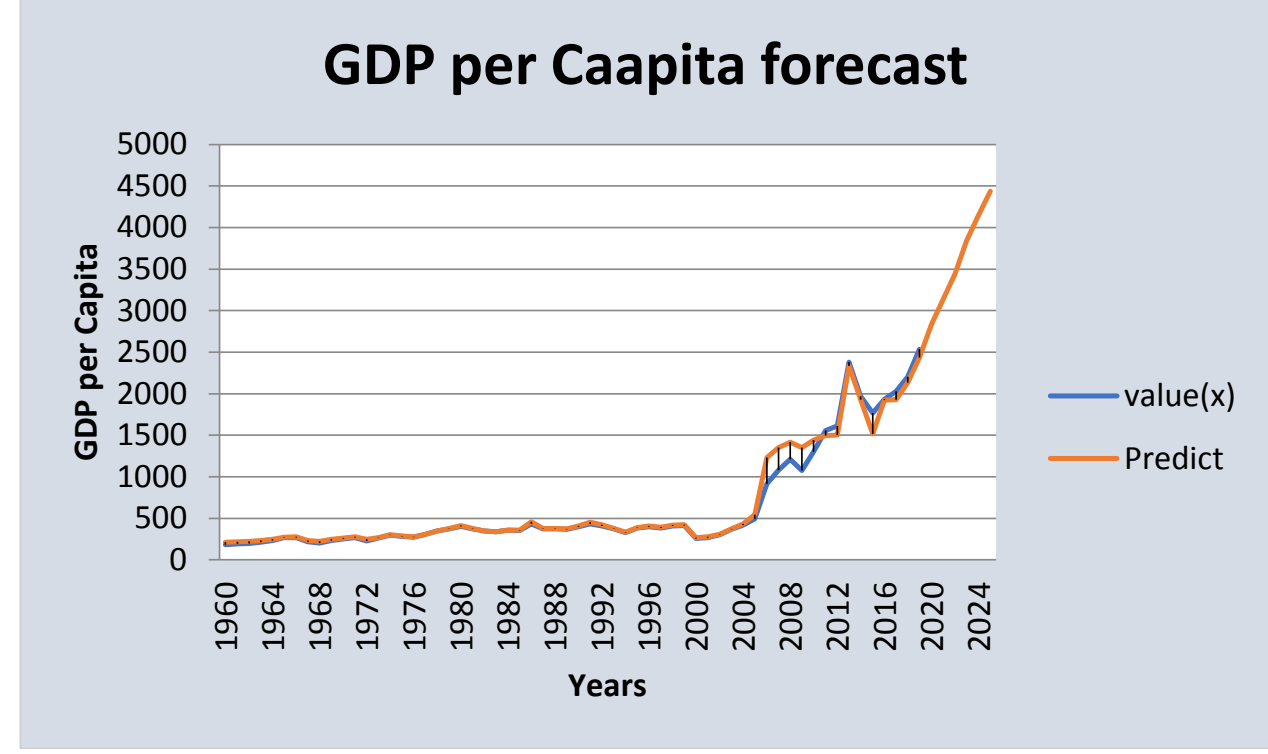

\subsection{Comparison of the two Forecasting Methods}

Plots from Figures 5 and 7 both show the forecasted lines against the actual over the period under study and beyond. One common thing is the similarity in both of the forecasted signals and plots. Though the simulated forecast (Laplace distribution) shows a more clear and logical output than that produced by the time series methods, both forecast tells the same story and that is an uptick of Economic prosperity for Ghana in 2020 and beyond. The consistency of the forecast plots imply that each of the modelling process employed is robust hence indicating the reliability of the trend lines and direction.

\section{ECONOMIC FORECAST OF GHANA AND THE COVID-19 PANDEMIC}

With forecasts giving positive indications of a promising Economic upswing in 2020 and beyond for Ghana it is also appropriate we indicate that this future is unrealistic particularly with increasing trends of Covid- 19 cases in Ghana and the world at large.

Covid-19 has progressively become a global canker and was first reported in Ghana on 12 March 2020 , it has since heightened to 2169 cases; with 229 recoveries and 18 deaths as at the close of 3rd May 2020. This translates to a recovery rate of about $11.0 \%$ and mortality rate less than $1 \%$. Anyway with respect to the whole populace just about $0.00723 \%$ of the roughly 30 million people are infected as of now.

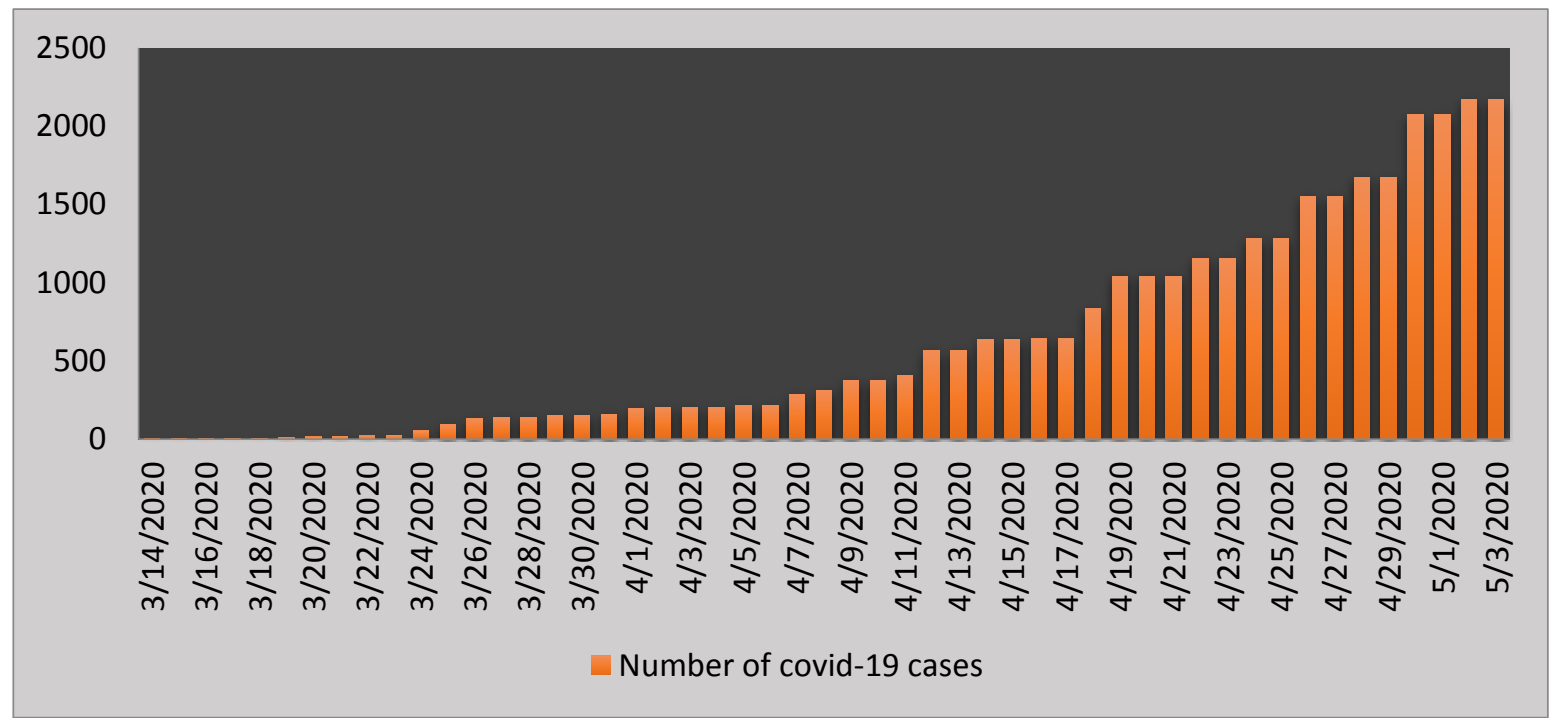

Figure 8. Covid-19 cases in Ghana as at $3^{\text {rd }}$ May 2020. 


\section{SJIF Impact Factor: 7.001| ISI I.F.Value:1.241| Journal DOI: 10.36713/epra2016

It is therefore important for the Government to restrict and stop the importation of the virus and furthermore contain its spread to a larger part of the people in light of the fact that a vast number of these individuals constitute the working force of the nation and their outputs contribute to the economic growth a great deal. Most of the response strategies put forward by the Government were largely motivated by countries earlier hit by the virus, especially Asia and Europe. These actions are: the closure of all borders, mandatory quarantine and testing of incoming travellers and partial lockdown of selected areas identified as high risk regions. With these harsh measures one can dare to dream that the number of infected persons will slow and perhaps flatten the curve but the pandemic's invincible economic impact cannot be overlooked. Some sectors through which the economy of Ghana would be exceptionally affected are in the direction of international trade, hospitality sector, investment avenues, FDI flows and oil revenues.

\subsection{Covid- 19's impact on the Ghanaian Economy}

With Ghana being a part of the international trade market and having international trade alone representing about $68.3 \%$ of its GDP, this at that point implies the pandemic is probably going to have a huge adverse impact on the country's international trade and reserves should it persists longer than foreseen. Globally, as many countries tend to look inwards and produce necessities for their own consumption, it implies that export trade would decline and revenues shrinked. Job losses will likewise be on the upsurge and this could thus disintegrate the economic gains achieved in recent years and fundamentally hinder Ghana's economic development. The top 5 import origins of Ghana being China (US\$3.3 billion), United States (US\$1.0 billion), Belgium (US\$0.7 billion), India (US\$0.7 billion), and the United Kingdom (US\$0.6 billion) have also been hit hard with this virus. In this light, the Government envisions a drop in anticipated GDP growth for 2020 at $2.6 \%$, which is essentially lower than the budgeted GDP growth of $6.8 \%$ computed earlier for the year.

As far as foreign direct inflows, the outbreak and associated lockdowns across the globe would prompt decreases in worldwide settlements and portfolio investments to developing economies including Ghana. Additionally FDI streams from the hospitality industry will be adversely impacted due to closure of borders and travel bans as a result of the pandemic. The fear of FDI slump will be further amplified by the fact that already some major multinational companies (MNCs) have on average revised their earnings downwards by $9 \%$. Developing countries MNCs would be the worst affected, with profit now projected to fall by $16 \%$. As long as this episode lingers, portfolio investments to emerging economies would decline and there are likely to be capital reversals as investors in advanced economies seek liquidity to enable them cope with economic downturns in their countries. Therefore, the Ghanaian economy is likely to suffer some reductions in portfolio inflows. Also, additional borrowing and related expenses that will be incurred is likely to increase the country's debt risk. The spontaneous increment in Government expenditures, particularly in the health sector, could adversely impact the fiscal deficit. Government estimates that events unfolding as a result of Covid-19, even with some mitigating measures, will result in a deficit of $6.6 \%$ of revised GDP, which is higher than the de facto fiscal rule of $5 \%$ established by the Fiscal Responsibility Law.

With Ghana presently being a net exporter of oil, income misfortunes are envisaged. An average crude oil price per barrel of US\$58 was conceived in the 2020 financial plan, however with unrefined petroleum costs presently hitting record lows, the income deficits could be colossal, and could prompt Ghana missing oil income targets. This would require an update of oil income targets and finding creative approaches to plug the financing escape clause. Ghana is among the main 10 fuel trading nations in Africa with fuel exports averaging US\$3.1 billion from 2016 to 2018. UNCTAD estimates that Africa would lose around US\$65 billion in fuel exports to the Corona virus outbreak. This would impact heavily on countries that are heavily dependent on fuel exports. At the moment, fuel exports comprise $23.3 \%$ of Ghana's total exports. This means, should the outbreak prolong, the impact on export revenues and possibly economic indicators of Ghana would be immense.

\section{CONCLUSION}

With time series modelling and forecasting and Monte Carlo simulation proving beneficial to the scientific literature in predicting trends, this year, Covid -19 has added an alternate curve to these expectations. Taking everything into account the GDP and economic growth of Ghana was expected to be on an upward trend quite similar to trends witnessed in 2019 if not better. However with current developments especially with the increase in number of Covid-19 cases worldwide, a lot of pragmatic measures have to be in place if the adverse effects of the pandemic are to be contained and mitigated. A few arrangements being set up by the Ghanaian Government worth complimenting are the establishment of a Corona virus Alleviation Programme (CAP) to facilitate economic recovery. 


\title{
SJIF Impact Factor: 7.001| ISI I.F.Value:1.241| Journal DOI: 10.36713/epra2016 \\ ISSN: 2455-7838(Online) \\ EPRA International Journal of Research and Development (IJRD)
}

\author{
Volume: 5 | Issue: 7 | July 2020 \\ - Peer Reviewed Journal
}

This will lower the cap on Ghana Stabilisation Fund (GSF) from the current US\$300 million to US\$100 million to allow for transfer of excess funds to the CAP. Likewise there will be a revision of the Petroleum Revenue Management Act (PRMA) to allow for withdrawal from the Ghana Heritage Fund to help in battling Covid-19. Bank of Ghana (BoG) has been mandated to reduce the policy rate by 150 basis points to $14 \%$ and drop the regulatory reserve requirement from $10 \%$ to $8 \%$ to increase supply of credit to private sector. The Government is additionally looking to advance due dates for filling tax returns by corporations from the standard 4 months to 6 months after end of the basis year. Also grant tax waiver penalties owed by taxpayers who redeem their outstanding liabilities by 30th June 2020, waiver of VAT on donations needed for fighting the pandemic, and instituting an email filing and direct transfer payment system to allow taxpayers file and pay taxes with the various Ghana Revenue Authority (GRA) offices remotely.

\section{REFERENCES}

1. Johanna Garnitz, Robert Lehmann \& Klaus Wohlrabe (2019) Forecasting GDP all over the world using leading indicators based on comprehensive survey data, Applied Economics, 51:54, 5802-

5816, DOI: 10.1080/00036846.2019.1624915.

2. Tao Wang (2016) Forecast of Economic Growth by Time Series and Scenario Planning Method - A Case Study of Shenzhen http://dx.doi.org/10.4236/me.2016.72023

3. Andrew Atkeson (2020) What Will Be the Economic Impact of COVID-19 in the US? Rough Estimates of Disease Scenarios NBER Working Paper No. 26867

4. Marco J. Lombardi, Philipp Maier (2011) Forecasting Economic Growth In The Euro Area During The Great Moderation And The Great Recession ECB Working Paper Series No 1379

5. Nicola M, Alsafi Z, Sohrabi C, et al. The SocioEconomic Implications of the Coronavirus and COVID-19 Pandemic: A Review [published online ahead of print, $2020 \mathrm{Apr}$ 16]. Int J Surg. 2020; $\quad$ S1743-9191(20)30316-2 doi:10.1016/j.ijsu.2020.04.018

6. Warwick McKibbint and Roshen Fernandot(2020) The Global Macroeconomic Impacts of COVID-19: Seven Scenarios*

7. Victor Platon, Andreea Constantinescu (2014) Monte Carlo Method in Risk Analysis for Investment Projects https://doi.org/10.1016/S2212-5671(14)004638

8. C. E. Onwukwe, G. O. Nwafor(2014) A Multivariate Time Series Modeling of Major Economic Indicators in Nigeria American Journal of Applied Mathematics and Statistics DOI:10.12691/ajams-2-6-4
9. Okoroafor, David O. K.; Adeniji, Sesan O.; Olasehinde, Timilehin (2018) Estimating and forecasting the impact of inflation on economic growth in Nigeria using threshold analysis Journal of Applied Statistics

10. Dr. Annie Uwimana, Dr. BI Xiuchun, Professor ZHANG Shuguang (2018); Modeling and Forecasting Africas GDP with Time Series Models; International Journal of Scientific and Research Publication(IJSRP) 8(4) (ISSN: 22503153),DOI:

http://dx.doi.org/10.29322/IJSRP.8.4.2018.p76 08

11. Bukvic, Ivana Bestvina (2019) Significance of Monte Carlo simulation in prediction of Economic projections: A Critical review. International Scientific Conference on Economic and Social Development - Rabat, 21-22 March 2019

12. Osés-Arranz, Ainhoa and Quilis, Enrique M., Probabilistic Population Projections Using Monte Carlo Methods: Spain, 2016-2066 (September 25, 2017). Available at SSRN: https://ssrn.com/abstract $=3042472$ or ht tp://dx.doi.org/10.2139/ssrn.3042472

13. Darko, Christian Kwasi (2015) : Determinants of Economic Growth in Ghana, ZBW Deutsche Zentralbibliothek für Wirtschaftswissenschaften, LeibnizInformationszentrum Wirtschaft, Kiel und Hamburg

14. Lily, Jaratin, Kogid Mori, Mulok Dullah, Sang Liem Thien, and Rozilee Asid. 2014. Exchange Rate Movement and Foreign Direct Investment in Asean. Economies Economics Research International 2014.

15. Dimple Goyal and Ritu Jain (2014). The Impact of FDI on Indian economy International Monthly Refereed Journal of Research in Management \& Technology 88 ISSN - 23200073.

16. Phillips, P. C. B., \& Perron, P. (1988). Testing for a unit root in time series regression. Biometrika, $\quad$ 75(2), 335-346. https://doi.org/10.1093/biomet/75.2.33

17. Im, K. S ., Pesaran, M., \& Shin, Y. (2003). Testing for unit roots in heterogeneous panels.Journal of Econometrics, 115(1), 53-74. https://doi.org/10.1016/S0304-4076(03)000927

18. Dickey, D. A., \& Fuller, W. A. (1979). Distribution of the Estimators for Autoregressive Time Series with a Unit Root. Journal of the American Statistical Association, 74 (366), 427-431. Https: //doi.org/ 10. $2307 / 2286348$ 